NBER WORKING PAPER SERIES

MONETARY POLICY WITHOUT QUANITY VARIABLES

Benjamin M. Friedman

Working Paper No. 2552

NATIONAL BUREAU OF ECONOMIC RESEARCH

1050 Massachusetts Avenue

Cambridge, MA 02138

April 1988

I am grateful to Kenneth Kuttner and James Stock for helpful discussions, and to the Harvard Program for Financial Research and the National Science Foundation for research support. The research reported here is part of the NBER's research program in Financial Markets and Monetary Economics. Any opinions expressed are those of the author and not those of the National Bureau of Economic Research. Support from The Lynde and Harry Bradley Foundation is gratefully acknowledged. 
NBER Working Paper \#2552

April 1988

\section{Monetary Policy Without Quantity Variables}

\section{ABSTRACT}

The collapse in the 1980 s of familiar relationships connecting money to either income or prices has thrown into question long-standing presumptions about the appropriate conduct of monetary policy. Once data from the 1980 s are included, tests of several kinds - - including simple regression tests, vector autoregressions tests, and tests for cointegration - all fail to show evidence of properties that would support using money as the central fulcrum of monetary policy... The Federal Reserve System, whether in response to these developments or for independent reasons, appears to have refocused monetary policy onto movements of short-term interest rates. The experience of the $1950 \mathrm{~s}$ and $1960 \mathrm{~s}$ suggests that this alternative approach also suffers from potentially serious drawbacks; which little recent research has addressed.

Benjamin M. Friedman

Harvard University

Littauer Center 127

Cambridge, MA 02138 
The collapse of the money-income relationship in the 1980 s has thrown into question long-standing presumptions about the approprlate conduct of monetary policy. Before the 1980 s economists and policymakers had long debated the role that aggregate measures of money (or credit) should play in the monetary policy process. Although issues of a non-empirical nature were also important in this regard -- for example, the desire for a system under which policymakers could be readily monitored and held accountable - the central issue was always the stability and relfability of the money-income relationship. Those who belfeved that it was highly stable typically sought to tie monetary polfcy more rigidly to fixed money growth targets, while those who doubted this stability sought to base monetary policy not just on money but on other varlables too (credit, for example), and in any case to make the connection between policy actions and either money or any other specific variables more flexible.

What was at issue throughout this perfod, however, was mostly the short-run conduct of monetary policy, and therefore the short-run stability of the moneyfncome relationship: fluctuations from quarter to quarter, or perhaps even year to year. Few economists or polfcymakers expressed doubts that the money-income relationship was highly siable over a time horlzon as long as the average business cycle, and therefore few argued that money growits should net follow a narrowly specifled trend over several years taken together. For those who were skeptical that a more activist policy could successfully carry out countercyclical stabilization anyway, the widely agreed upon stability of the money-income relationship over longer horizons led naturally to a fixed money growth policy even in the short cun.

The events of the 1980 s have been so important for thinking about monetary policy precisely because they have contradicted this more fundamental confidence In the stabllity of the money-income relationship in the longer run. For the 
five years ending at mid 1987 , the average growth rate of the Ml money stock was 10.88 per anum -- far above that for any sustained period in tecent U.S. experience. Vet inflation has been modest by historical standards, and real income growth for this perlod as whole has haxdly beer extraordinary compared to previous U.\$. business cycle expanslons. It is difficult to escape the conclusion that, not just for a year or a calendat quarter but over an entire half-decabe, money growth has simply been irrelevant to any outcome that matters for monetary policy.

Anglogous reistionships between income or prices and other financlal quantity variables have fared little or no better during this period.: Broader measures of money, or the nonetary base, or messures of credit have ail fluctuated in patterns bearing little visible connection to any plausible objective of monetary policy. As a result, the entire role of such quantity variables in the monetary policy process -- either money or any of the others -is now practically devold of empirical support based on recent experience. At the same time, however, no one has satisfactorily outlined an alternative monetary policy Examework that does not rely on such variables. The result is a vacuum at the center of the monetary pelicy process.

\section{Money and Incone, Money and Prices}

One plcture and one example from the recent literature are sufficient to place in perspective the collapse of the relationship berween money and either income or prices in the 1980s.

First, the picture: Figure 1 plots the ratio of the Ml money stock to nominal GNP For each quarter from 1959:I (when the redefined $M 1$ series begins) to 1987:III. Through 1980:IV the money-income ratio followed the familiar 38 per annum downard trend that practical discussions of monetary policy had come to treat as if it were natural constant, whth standard deviation around the 


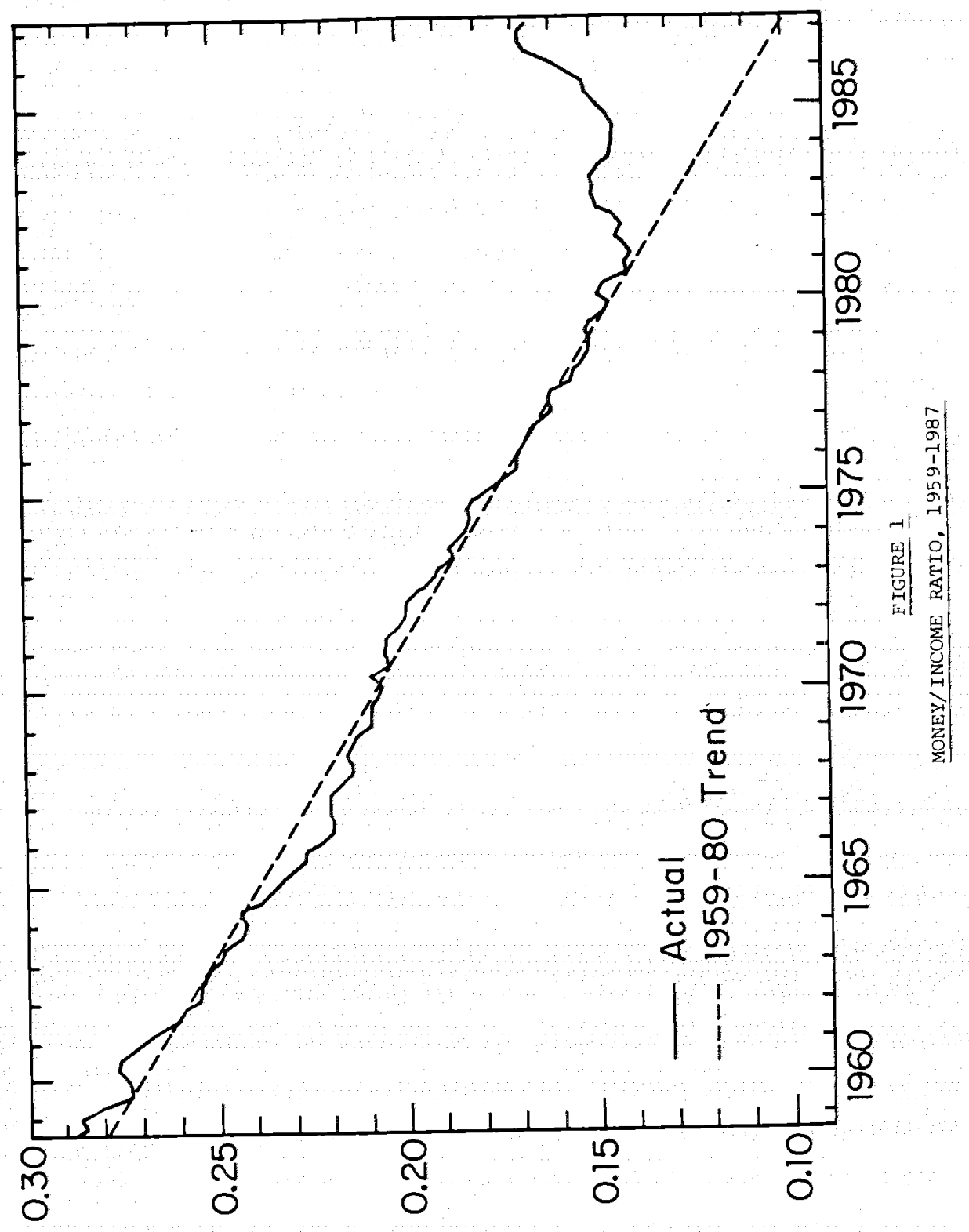


trend of oniy .0044 compared to a 1980:IV yajue of 1466 . Since 1980 the shortrur fluctuatons have been visibly wider. Hore fmportanty, the downard trend has not just disappered but reversed course. A simple extrapolation of the 1359-80 trend amplies money-income tatzo of .0991 by 1987:IIT. The ectual value mas. 1662 , greater by more than 15 standard atiations.

The analogous relationship for credit, the outgtanditg fndebtednes of all

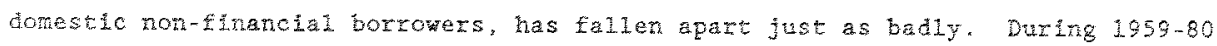
the credit-income ratho shibled a standard deviation of only .0is7 faround a

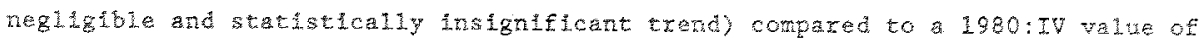
1.3782, By 1937:I the gap between the actual zatio and the trend extropolation tas nore than 23 standard deviation.

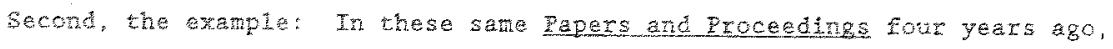

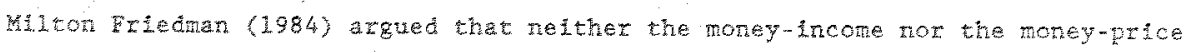
relationship had broken down after october 1979, when the Federal Reserve experimented with a poicy centered on money growth targets. He instead argued thet both relationshaps hat continged to hold up if lnterpreted correctiy. For the

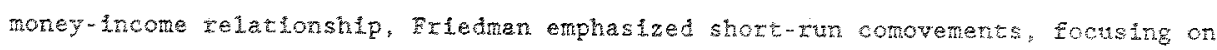

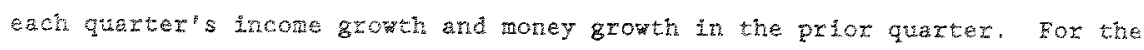
money-price relationship, he enphasized longer-run conovenerts, focusing on average finflaton over successo two-year intervals and awerage noney growth ower the prot tor years.

Since Friedian wrote, however, both of the relationships on which he based hs argunents have cven changed sign. The correlation between the respective growh rates of nominal incore and M lagged one quarter was. 45 during the 1979:IV-1983:IV sample he used. The same correlation computed for 1984:I-1987:II is minus. 10 . Frledman did not report a cortelation for the biennial growth rates of prices and lagged money but simply showed the deta for each successive 
blennium, beginning with 1973:III-1975:III for the GNP deflator and 1971:III1973:III for $M 1$. The direction of the change in M1 growth in each of these perlods had foretold the direction of the change in inflation in the next, and on this basis Friedman predicted, "The increased rate of money growth in the 198183 biennium suggests that we have passed the trough in inflation and that Inflation will be decidedly higher from 1983 to 1985 than it was from 1981-83." Instead; Inflation turned out to be lower during 1983:III-1985:III than during 1981:III-1983:III, and it was lower st111 during 1985:III-1987:III desplte continued high money growth during 1983:III-1985:III. The correlation computed over the five observations Frledman exhlbited was .70 . Computed over those five observations and the two more that are now avallable, the correlation is minus 23.

\section{Money and Credit as Information Varlables}

The breakdown of such simple money-income or money-price relationships casts doubt on the use of money (or cred1t) as a target of monetary policy In any rigld, mechanical sense.. It need not preclude a useful role for such varlables In the monetary policy process, however, as long as their movements provide Information about subsequent fluctuations of income or prices, or any other outcomes that monetary policy seeks to affect. 1 A policy framework based on aggregate measures of money (or cred1t) used as "Information variables" is more flexible, and hence more complicated and harder to monitor externally, than a framework based on such varlables used as policy targets. The greater the extent to which the relationships that connect these varlables to income and prices are affected both by other variables (11ke Interest rates) and by stochastic shocks, however, the greater are the relative merits of an information variable approach compared to a sinpler targeting approach: 
sense. Kuttrer and I (1987) have shown that evidence of a veriety of forms, conmecting woney $(0 x$ credit) to income and prices, has progressively deteriorated since 1979 .

Table 1 shows $\bar{R}^{2}$ statstics for the estrmetion of "St. Louls" equations relating the quateriy growth rete of nomina income to lagged growth tates of several cespective thanchal quantity variabies and the lagged growth rate of high-employment federal spending, over three sample periods. 2 For 1960:II1979:III - that Is, unt1 the incroduction of the new monetary policy procedures - these equations al exhibit the faniliar Hodes success in accounting for

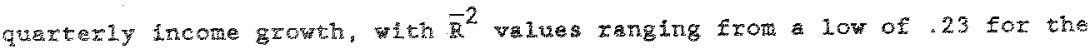
monetary base to high or .32 for Ki. Futending the sampie to inelude data

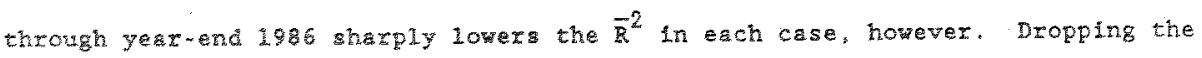

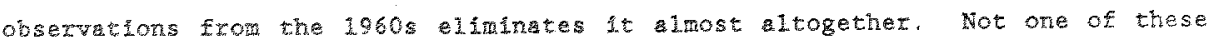
equations for the note tecent period exhiblts $\overline{\mathrm{R}}^{2}$ even as high as 10 .

Table 2 shoms F-segtistics for tests of the mull hypochesis that all of the coeffleterts on lagged M1 growth are zero in equations from several series of wector autoregressons. ${ }^{3}$ 点

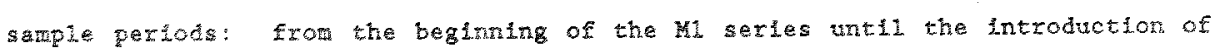
new ronetary policy procedures, then through she most recent data ayallabie as of the time of Heting, and then for the nost recent detwithout the 1960 s.

In the contert of the informston varlable approach to uonetary policy, the much debated Lsue of wether statistical experiments ifke these constitute valid tests of "causelity" is beside the point. Whet matters is simply whether the movements of some financial quentity convey information about future movements of income or prices that is not already contaned in observed movements of incone or prices themselves. If so, then wonetary policy can explott that information by systematically reacting to obserged movements of these variables, regardless of 
Table 1

Coefficient of Determination for Nominal Income Equations

\begin{tabular}{lccc} 
Monetary Base & .23 & .15 & .02 \\
M1 & .32 & .11 & .02 \\
M2 & .27 & .19 & .06 \\
M3 & .27 & .16 & .09 \\
Credit & .28 & .10 & -.02 \\
\hline
\end{tabular}


Table 2

F-Statistics for Information Value of Money (MI)

Fiscal Variable

Included

$\begin{array}{cccc}Y & 6.16^{a} & 2.63^{b} & 1.42 \\ X & 1.98 & 1.91 & 1.33 \\ P & 3.62^{b} & .68 & .47\end{array}$

Fiscal Variable

Included

\begin{tabular}{cccc}
$Y$ & $5.99^{\mathrm{a}}$ & $2.83^{\mathrm{b}}$ & 1.92 \\
$\mathrm{X}$ & $2.17 \mathrm{c}$ & $2.21 c$ & 1.91 \\
$\mathrm{P}$ & $3.65^{\mathrm{b}}$ & .75 & .88 \\
\hline
\end{tabular}

$Y$ - nominal GNP

$x=\operatorname{real} G N P$

$F=$ GNP price deflator asignificant at .01 level

$\mathrm{b}_{\text {significant at } .05 \text { level }}$

$c_{\text {signiffcant at } .10 \text { level }}$ 
prices themselves. If so, then monetary policy can exploit that information by systematically reacting to observed movements of these variables, regardless of whether this information reflects true causation, reverse causation based on anticipations, or mutual causation by some independent but unobserved force.

As of 1979 , the avallable evidence strongly supported the view that observed fluctuations of MI in the United States did contali such information about future movements of U.S. income and prices. By contrast, the same experiments carried out with data for the most recent 18 years provide no support for the view that fluctuations in ML carry information about future income and prices that is not already contalned 1n fluctuations of income and prices themselves. Not one of the F-statistics for this more recent sample is signiflcant at even the .10 level. Once aga1n, what $1 \mathrm{~s}$ true for $M 1$ is also true for other money and credit aggregates. The F-statistics for analogous experiments carried out with W credit in place of MI show the same pattern of changing significance as in Table 2. Not one of the F-statistics for M2, and not one for credit, is signiflcant at the .10 level for the 1970:I-1987:II sample.

Not surprisingly, such findings have prompted a search for ways to "fix up" this form of test of the money-1ncome relationship, just as a much more intenslve search, which began even earlier, has sought to flx up the money demand function. Stock and Wetson (1987), for example, showed that with the right specification lagged $M 1$ was in fact significant in equations for real income (proxied by 1ndustrial production) in tests based on monthly data for 1960:2-1985:12. For a system including money, Income, prices and an interest rate, together with a time trend, they reported an F-statistic of 3.04 (easily significant at the .01 level) for the nuli hypothesis that all of the lagged money coefficlents were zero. As Kuttner and I have shown, however, merely extending the sample for this experiment through 1987:9 reduces the F-statistic to 1.80 , just barely 
significant at the .10 level (p value.0994), and changes stock and Hatson's results for the other systems that they investigated as well.

Table 3 shows that the most recent experience has also eliminated statistical support for the hypothesis that Income and money (or credit) are cointegrated. The table shows Dickey-Fuller t-statistics for the null hypothesis of no cointegration between nominal income and each of several financial guantizy variables, in the presence of a possibly nonlinear time trend. 4 The results shown are based on quarterly data for three samples, which here differ only in theit respective end-points: before the introduction of new monetary policy procedures, before the abandonment of those procedures, and the latest data available as of the time of riting. At least for $M 2$ and credit, the data through 1979:III warranted rejecting the null hypothesis of no cointegration with nominal income at the .05 level. The data through 1982:II did so as well, albeit only at the .10 level. For data through 1987:II, however, there is no evidence of cointegration with nominal income for any of these financial quantity variables. 5

\section{Questions About Konetary Pollcy Since 1982}

If it is difficult to escape the conclusion that financial quantity variables have lost their relevance for monetary policy in the 1980 , it $1 \mathrm{~s}$ also difficult to escape the conclusion that the Federal Reserve System has responded to this development by conducting monetary pollcy primarily with reference to short-term nominal Interest rates (and, indirectly, dollar exchange rates). One reason for drawing this conclusion is simply the return to interest rate stability after the Federal Deserve "suspended" its M1 target in 1982. The standard deviation of the month-to-month change in the three-month U.S. Treasury b111 rate rose from .428 during $1970: 1-1979: 9$ to 1.548 during $1979: 10-1982: 9$, and then fell to 32 during 1982:10-1987:9. Another reason is that what movements 
Table 3

Dickey-Fuller T-Statistics for Cointegration Tests

\begin{tabular}{|c|c|c|c|}
\hline Monetary Base & -2.90 & -3.03 & $-0.22^{a}$ \\
\hline & $-1.53^{a}$ & $-1.61^{a}$ & $-0.34^{a}$ \\
\hline & $-3.67^{b}$ & $-3.40^{a, b}$ & $-2.69^{\mathrm{a}}$ \\
\hline It & $-3.60^{b}$ & $-3.28^{c}$ & $-0.09^{a}$ \\
\hline
\end{tabular}

augmented Dickey-Fullex t-statistic

b

significant at .05 level

c significant at 10 level 
in short-term interest rates have occurred since mid-1982 have shown little apparent connection to fluctuations of the major monetary aggregates (or credit). or to deviations of these aggregetes from the corresponding offlclal target ranges.

The success of U.S. monetary policy in macroeconomic terms during these years notwithstanding, a return to approximately the same monetary framework that the Federal Reserve employed a quarter-century ago should give cause for some concern - not least because of the systematic errors that the Federal Reserve made under that policy. The extensive analysis of U.S. monetary policy during the first two decades or so following the Treasury-Federal Reserve Accord, Including research carried out at the time as well as subsequently, has documented three problems in particular. Each bears renesed consideration now that the Federal Reserve has returned to wat amounts to a policy framework centered on controlling nominal interest rates.

First, and most obviously, this framework had no nominal quantity to anchor the price level. Although inflation was not therefore inevitable, there was little protection against it when inflationary pressures intensified in the late 1960 s and especlally in the 1970s. For some years following Sargent and Wallace's (1975) demonstration that basing monetary policy on nominal interest rates left the price level indeterminate in model with "rational" expectations and perfectly flexible prices, many economists eschewed analysis of such a policy framework altogether, and concentrated only on policles based on controlling money. As McCallum (1981) has shown, however, even In Sargent and Wallace's model price indeterminacy results only when the central bank takes no account of prices (or any other nominel varlable) in choosing the level at which to set interest rates. 6 Especially in a context that allows for rigidities in price setting behavior as mell as more realistic representations of expectations, no 
one knows to what extent it is practically possible to avold inflation wth a monetary policy framework based on nominal interest rates, or how best to structure such a polfcy to achieve that end.

Second, once Inflation did emerge, Federal Reserve offlclals (and many other people too) ofren falled to distinguish nominal from real interest rates. As a result, they often associated higher observed interest rates with a tighter policy stance even when the increase fn nominal interest rates mezely kept pace with, or even fell short of, rising fnflation expectations. In ight of the enormous attention subsequently devoted to the distinction between nominal and real interest rates, both in the research 1tezature end the popular level, it would be surpxising to see this mistake repeated in such an obvious wey. Nevertheless, fnfercing "the real interest rate" is hardiy straightiorwed. Expectations of future Inflation are unobservable, and dfferent people may hold different expectatons anyay. Different people and different institutions also face different tax rates.

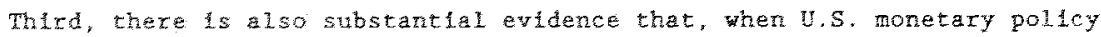
telied primarily on nombel anterest rates the past, Federal Reserve offichas systematcaly confused the level of Interest rates as the operating instrunent of pollcy wh the level of interest mates as an ultmete objective of policy. As a result, they usually delayed too long before raising or lowering interest. rate levels, and even then made changes of insufficlent magnitude. Although this error too has recelved enotmous attentlon, more in the research literature than in popular discussions, no one knows whether it is now possible to design monetary policy framework based primarly on interest rates that can provide adequate safeguards aganst repeating it. St1Il less has anyone laid out in any detall what such safeguards might be. 
The evidence from recent experience is clear on the potential role of financial quantity varfables in the monetary policy process, and it is not positive. Perhaps the time has come for economists to turn at least some of the effort they are now spending on trying to overturn the evidence on these variables toward thinking about how best to conduct monetary policy without them. 


\section{Footnotes}

1. See, for example, Kareken et al. (1973) and Friedman (1975, 1983).

2. These equations differ from the St. Louis specification only by omitting the contemporaneous value of each independent variable.

3. Each autoregression includes four lags on each variable in the system, plus a constant. All variables are in log differences.

4. The cointegrating equation is in each case $\ln \left(f_{t}\right)-\ln (a+b * t)+c * \ln \left(y_{t}\right)+e_{t}$ where $f$ is the financial quantity, $y$ is nominal income and $e$ is a disturbance term. The nuli hypothesis of no cointegration means that e is nonstationary. The values shown are augmented Dickey-Fuller t-statistics in cases in which higher arder autocovariance of e is present, and ordinary Dickey-Fuller $t$ statistics otherwise.

5. Tests carried out in the forms $\ln \left(E_{t}\right)=a+b * \ln \left(y_{t}\right)+e_{t}$ and $\left(f_{t} / y_{t}\right)=$ $a+b \times t+e_{t}$ also show no evidence of cointegration for any of these financial quantity variables in the data through $1987: 11$.

6. What Mecallum actually showed was that taking account of money in setting the interest rate resolves the price indeterminacy His result readily generalizes to the inclusion of any nominal variable, however.

7. See, for example, Brunner and Meltzer (1964) 


\section{References}

Brunner, Karl, and Meltzer, Allan H. The Federal Reserve's Attachment to the Free Reserve Concept. Washington: U.S. Government Printing Office, 1964.

Friedman, Benjamin M. "Targets, Instruments and Indicators of Monetary Policy." Journal of Monetary Economics 1, (October, 1975), 443.473.

. "The Roles of Money and Credit in Macroeconomic

Analysis." Tobin (ed.), Macroeconomics, Prices and Quantities: Essays in Memory of Arthur M. Okun. Washington: The Brookings Institution, 1983.

, and Kuttner, Kenneth N. "Money, Income and Prices after the 1980s." Mimeograph: National Bureau of Economic Research, 1987.

Friedman, Milton. "Lessons from the 1979-82 Monetary Policy Experiment." American Economic Review 74, (May, 1984), 397-400.

Kareken, John H., Muench, Thomas, and Wallace, Neil. "Optimal open Market Strategy: The Use of Information Variables." American Economic Reyiew 63 (March, 1973), 156-I72.

McCallum, Bennett T. "Price Level Determinacy with ar Interest Rate Policy Rule and Rational Expectations." Journal of Monetary Economics 8 , (November, 1981), 319-329.

Sargent, Thomas J., and Wallace, Neil. "Rational' Expectations, the Optimal Monetary Instrument, and the Optimal Money Supply Rule." Journal of Political Economy 83, (April, 1975), 241-254.

Stock, James H., and Watson, Mark W. "Integrating the Evidence on MoneyIncome Causality." Mimeograph: National Bureau of Economic Research, 1987. 